\title{
LESBIAN PERFORMATIVITY AND HETERONORMATIVY IN THE NOVEL LESBIAN LAKI-LAKI BY DEOJHA: JUDITH BUTLER
}

\author{
Agung Wijaksono, Nurhadi \\ Postgraduate Program, Yogyakarta State University, Indonesia \\ Email: agungwijaksono2503@gmail.com, Nurhadi@uny.ac.id
}

\section{ARTICLE INFO \\ Received: 05-01-2022 \\ Revision: 13-01-2022 \\ Received : 18-01-2022 \\ Keywords: \\ Performativity; \\ heteronormativity; queer \\ theory; Judith Butler}

\begin{abstract}
Lesbians are a testament to sexual diversity in society, but in reality, the existence of minorities is still faced with the dilemma of norms in society. The condition occurs since people still acknowledge heteronormality or only consider heterosexual orientation deemed normal. This study was designed to describe lesbian performativity and heteronormativity in the novel Lesbian Laki-Laki (Male Lesbian) by Deojha's using the Judith Butler's theory of Queer. This study used a descriptive qualitative research method. The results showed that gender and sexual identity discourse are constructed by language and body markers. The heterosexual discourse of acceptable gender identity only involves masculinity and femininity, then sexually divided into two parts, called male and female. The analysis also proved that although the novel voiced lesbian order but still in the norms of heteronormativity.
\end{abstract}

\section{Introduction}

The main problem faced in Indonesia within the scope of sexual studies is queer acceptance. In society, sex is often divided into two, called male and female. These sexual differences are associated with masculinity and femininity that are considered to be attached to a certain gender, which are formed and associated culturally. The relationship between a certain gender ultimately creates stereotype that ideally a male should be masculine, whereas a female should be feminine (Fakih, 2013).

In reality, gender and sexual differences are not static since different cases are often found. In society, for instance, there are men who are feminine, on the other hand there are women who are masculine. There are men who are not masculine, even refuse to be masculine, or vice versa, women who tend to be masculine and refuse to be feminine. From this phenomenon, the terms transgender and homosexual are known. Homosexual person is a person whose sexual orientation whether manifested or not, is directed at the same sex (Oetomo, 2001). In addition, homosexuality refers to interesting attracted to feelings (affection, emotional connection) and or erotically, both dominantly (more prominently) or exclusively (solely) towards people of the same sex, with or without a physical relationship (physical) (Oetomo, 2001).

Homosexuality is a proof of sexual diversity in society, but in reality the existence of these minorities is still faced with a dilemma. The society considers these people to be disgusting people (Blackwell, Ricks, \& Dziegielewski, 2004). This condition occurs since the generally recognized sexual orientation by society is sexual attraction to the opposite sex or heterosexual. The phenomenon of homosexuality and transgenderism has previously been studied by (Centhini \& Lesbian, n.d.). This research examines several Indonesian novels, namely Ayu Utami (Larung), which was followed by subsequent authors, such as Herlinatiens

$\begin{array}{ll}\text { How To Cite: } & \text { Wijaksono, A., \& Nurhadi (2021) Lesbian Performativity and Heteronormativy in The Novel } \\ & \text { Lesbian Laki-Laki by Deojha: Judith Butler. Journal of Social Science. 3(1). } \\ & \text { https://doi.org/10.46799/jss.v3i1.254 } \\ \text { E-Issn: } & 2721-5202 \\ \text { Published By: } & \text { Ridwan Institut }\end{array}$


(Line Edge of a Lesbian), Dewi Lestari (Supernova), Nova Riyanti Yusuf (Mahadewamahadewi), Ratih Kumala (Tabularasa), and Dewi Sartika (Dadaism). In all these novels, homosexuals, especially lesbians, are discussed, which is the central theme and problem of the characters in the novel.

One of the reforms that were intensified by the female authors was related to the issue of lesbians. The lesbian community is an interesting topic to pay attention to. This community is a marginalized community in social life. Culture has long created constructs that corner this community into minority life and create unavailable breathing space. this community are forced to take the freedom in realizing individual self-actualization (Kasnadi, 2017). Lesbian is considered a violation, sexual orientation deviation, even a sin in the eyes of society and religion, but in fact this community still exist (Juditha, 2014).

Queer was originally a word used as a mockery for homosexuals (Barry, 2010). Queer, in terms of sexuality, is also interpreted as a conceptualization of nonheterosexuality, especially same-sex sexuality (Setyorini, 2011). In addition, Jagose and Genschel (1996) explained that in the queer view, what is referred to as gender and sexuality are unstable and incoherent identities. This term is then used in the scientific field as a queer study relating to the study of gays or lesbians. Gay is a male's physical and mental attraction to the same sex or to fellow males, while lesbian is a female's physical and mental attraction to other females (Wahyudi \& Widhiasih, 2015).

Butler views identity as something that is constructed and carried out. Lesbian self-identity is influenced by the environment, both the family environment and the society community (Yanti, 2016). Butler questioned the position of transgender people, transsexuals to third world women, whose gender and sex identities are often considered deviant and questioned. Therefore, Butler states sex cannot be used as the basis for social and cultural construction since sex, including gender, has been formed before an individual's body is present until it display a certain gender form. Butler wrote:

"If gender is the cultural meanings that the sexed body assumes, then a gender cannot be said to follow from a sex in any one way..... If the immutable character of sex is contested, perhaps this construct called "sex" is as culturally constructed as gender; indeed, perhaps it was always already gender, with the consequence that the distinction between sex and gender turns out to be no distinction at all." (1990: 6-7).

Butler's explanation that the biological body has been constructed to represent a particular gender. Queer theory questions and opposes gender identification by arguing that not only gender (masculine and feminine) but sexual (male or female) is a social construction. Butler's theory is conceptualized with performativity, namely an action which then undergoes changes to each individual's body that is changed from the original. Like a lesbian, one could say these people were impersonating a man (Butler, 2002).

Rich in Crawford (2000: 96) argues that lesbianism is more of a continuum than a category. Relationships of a sexual nature are only one point on the continuum, which includes "women's passion for women" as well as "women's choice of women as friends, mates, and community". For Butler, the category of women emerges from a process that produces gender, a process called "performativeness". i.e. a performative is "discursive practices that produce or establish what is later mentioned as marking constitutive power and discourse production" (Butler in Ritzer, 2012). Performativity is meant by Butler is a gender identity that is formed through roles, actions, words, and desires that include performance that is influenced by the environment of each individual which is then realized in personal embodiment. In interpreting a person's identity, it can be determined from three things, there are performativity of appearance and physicality, performativity of a lesbian conversation, and performativity of a lesbian's sexual activity.

The confinement of homosexuality occurs as a result a heteronormativity system existence. Heteronormativity is a social construction that shows sexual relations according to the norm are heterosexual. According to (Alimi, 2004), in the heteronormativity system, sexual activity is positioned as a procreative activity, which aims to produce offspring. In order to 
reproduce, males must be paired with females, and vice versa. Sexual practices that are not procreative oriented are considered deviant since its purposes are limited to recreation, such as sexual acts before marriage, masturbation, and homosexuality. Men or women who cannot produce will be considered as men or women who are not ideal. Thus, the only accepted sexual relationship is heterosexual, that is, between a man and a woman. A non-heterosexual relationship is considered an unkind, unnatural, deviant, or abnormal relationship. These forms of sexuality which are considered non-normative have been restrained by some people.

In heteronormativity marriage becomes an obligation. According to Simone De Beauvior in Second Sex, marriage is a traditional destiny given to women by society. Celibate (single) women are defined as people who are frustrated, rebellious, or even indifferent to the institution of marriage (Beauvoir, 2003: 225). From this, an understanding and norm was born that women must always be passive, in control, have personal control, be in the domestic sphere. On the other hand, men are identified as having freedom, power, being active, assertive, and being in the public sphere. In the patriarchal discourse of sexuality, women are positioned as objects and men as subjects. Women are burdened with social responsibility as a means of reproduction. Since the main and natural sexual behavior is only judged based on its function, namely to get offspring or procreation. Other sexual activities, such as recreation and relationships, are prohibited and considered unjustified.

\section{Method}

This research used a descriptive qualitative research method. The approach used is the study of Judith Butler's queer theory to understand gender. The data source in this research is the Indonesian novel entitled Lesbian Male by Deojha.

The research data is in the form of textual units in the novel that represent the performativity and heteronormativity of lesbians. From the results of this description, it can be seen that gender identity and heteronormativity occur in society. The data were collected using reading and note-taking techniques. This means that the researcher will conduct intensive reading of the male Lesbian novel by Deojha in order to obtain accurate data.

The research data that has been obtained are then analyzed using descriptive analysis techniques. The data were analyzed based on the formulation of the problem and the framework of thinking. The data analysis techniques are associated with forms of lesbian performativity and heteronormativity.

\section{Results And Discussion}

In this research, several things will be discussed. First, the gender concept of Judith Butler which describes the performativity in Deojha's novel Lesbian laki-laki (Lesbian Male) by Deojha defined through the main character Sangkhala Senja in the process showing the performativity of appearance and physicality, the performativity of a lesbian conversation, and the performativity of her sexual activities. Second, the main character in responding to the dominance of heteronormativity.

\section{Appearance and Physical Performativity}

Appearance and physical performativity is the second way to know a person's identity. The appearance of a lesbian usually emphasizes masculinity rather than femininity.

As a butchie (lesbian who plays as a male), Sangkhala Senja is described as a masculine figure. In this case, masculine in the sense of women who behave like men. Even in appearance, Sangkhala Senja looks very masculine. Sangkhala Senja's attitude is inversely proportional to her older sister, Jingga, who has a feminine appearance, as in the quote.

"He is north and I am south. She is feminine and I am very masculine. Not a masculine in literal meaning. He's sweet and I'm cranky". (Deojha, 2012: 13).

Based on those quote, the discourse of identity is imaged on the physic. The materiality of the physic (body) is the main marker of the existence of the subject. Precisely, gender construction that often marginalizes one as a sub, that is women, occurs in it. This can be seen, for example, when Sangkhala Senja positioned himself as a masculine person both in attitude and appearance. Sangkhala Senja grows into a 
new person when he is with his adoptive family. Sangkhala Senja's attitude, which began to feel strange when wearing women's clothes, even preferred to play with the robots rather than dolls, as in the quote.

"From there I was formed into a new Sangkhala Senja. Who began to feel strange when wearing women's skirts and clothes, started to like robots and toy cars rather than dolls." (Deojha, 2012: 16).

In addition to getting comfortable with playing with robots, in the Sangkhala Senja school environment, she prefers basketball extracurricular. In the home environment, Sangkhala Senja prefers to do male activities, such as repairing roof tiles. Over time, Sangkhala Senja also felt more attracted to the beauty of a woman's body. This can be seen in the following quote.

"Those who prefer basketball extracurricular to sewing. I'd rather fix the tiles than cook with my mom. Also more interested in seeing a woman's chest than a man's burly body. More and more masculine spirit in a family that is more democratic, with my three older brothers and a married couple whom I am used to calling mama and papa." (Deojha, 2012: 17).

Sangkhala Senja is described as a female character who later grows up to become a lesbian. In this case, Sangkhala Senja is positioned as a butchie (lesbian who plays a male role). This is reinforced by the personality and habits of Sangkhala Senja which are more directed towards a masculine soul.

\section{Lesbian Conversation Performativity}

The performativity of sexual conversation refers to how a lesbian interacts and provides codes that justify that she is a lesbian to the other person.

Sangkhala Senja as a child of such royal family in Sulawesi, Sangkhala Senja does not really care about her lineage. A hard worker and never give up on life. Sangkhala Senja is always confused when someone asks her since when she became a lesbian, thus she likes give nonsense answers as she pleases. Sangkhala Senja, who was 22 years old, decided to become a lesbian and entered several communities. Sangkhala Senja does not care about the opinions of common people towards her, so she considers lesbians as a gift and even Sangkhala Senja recognizes herself as a lesbian, as in the quote.

"The common people call them lesbians. And some in the community themselves call it belok (turned or not straight). I myself call it a gift. Yes, I'm a lesbian, I am belok. Then what?". (Deojha, 2012: 5).

Sangkhala Senja also slowly began to reveal her identity as a lesbian, even though it was all difficult but Sangkhala Senja still always answered and acknowledged her personality as a lesbian. Sangkhala Senja has always considered lesbians as a gift, as in the quote.

"Simply put, I did choose to be a lesbian, to be a butchie. That is life, living what has been given to me." (Deojha, 2012: 22).

Even though Sangkhala Senja acknowledged and answered about her existence as a lesbian, that is as a butchie. Although it was all difficult, Sangkhala Senja always answered and acknowledged her personality as a lesbian. Sangkhala Senja has always considered lesbians as a gift. The urging of questions also came from her family, as can be seen in the following quote.

"So you're lesbians?" asked Mr. Bhummy again.

"Yes. What's it called?" I'll answer it again." (Deojha, 2012: 22).

The quote shows that Sangkhala Senja admits that she is a lesbian because of the pressure from her step brother Mr. Bhummy. The incident occurred when Sangkhala Senja invited her lesbian partner to Jogja to meet her family. Mr. Bummy knows her behavior as a lesbian because of her attitude and behavior towards the female friends she brings. Sangkhala Senja's openness to his family made her feel worried and restless as in the following quote.

"Maybe since they can already guess that $90 \%$ of my answer is, 'yes I'm a lesbian'. Now it's just me who is restless and mentally prepared more." (Deojha, 2012: 25).

This quote shows that Sangkhala Senja is still restless and mentally prepared. Mentally prepared to face her family, work environment or maybe even her closest friends. Not only in the family, but also in the work environment Sangkhala Senja has to give up her job just because she is a lesbian, as in the following quote. 
"Sorry, but are you really... a lesbian?" Oo, this is where the problem lies.. lesbian". (Deojha, 2012: 53).

Her boss questioned Sangkhala Senja's certainty about the truth that she was a lesbian. That makes Sangkhala Senja forced to resign from her job. Sangkhala Senja's decision to love fellow women and reveal that she is a lesbian might make different reactions to various parties. It seen in the following quote.

"I am Sangkhala Senja who loves women even though I am also a woman. I told you, I'm a lesbian." (Deojha, 2012: 170).

\section{Sexual Activity Performativity}

The performativity of sexual activity in a lesbian can be seen from how she treats her lesbian partner. The sexual activity of a lesbi is not the same as the sexual activity of men and women. The form of lesbian sexuality can be seen from their performativity and imagination in dealing with their lesbian partner. It seen in the following quote.

"Strive to think positive and try to sleep. Half-closed, she began to act. Her mouth naughty kissing my sensitive area. I got goosebumps and held back a little desire. I really want to sleep even though I have thoughts of making love first. But considering how annoying she was all day, she had to work hard to seduce me." (Deojha, 2012: $31)$.

Lesbian activities can take the form of kiss or kissing and even lead to actual sexual intercourse. Sangkhala Senja's lesbian activity while kissing Fitri, her first lover, who is hypersexual, begins to react to Sangkhala Senja. Starting from kissing her sensitive area to openly inviting Sangkhala Senja to make love.

Sangkhala Senja's love journey begins with Fitri. Fitri is the first lover of Sangkhala Senja, who is too hypersexual (infatuated with sexuality). In the end, Fitri is not a woman who is loyal to Sangkhala Senja as in the quote.

"She's not a loyal woman, I knew from the start because I saw her before my own eyes she kissed her ex-butchie when I and her only had a one-week relationship." (Deojha, 2012: 35).

Then Sangkhala Senja's love journey continues to Rinjani's character. Rinjani is one of Sangkhala Senja's friends who offered her a temporary place to stay. But it turns out that there is a motive behind all of Rinjani's kindness towards Sangkhala Senja. Rinjani is also not a lesbian, she is just trying to feel like being a lesbian as shown in the following quote.

"In fact, my approach with her was longer than my previous experiences. The problem is she iss not a lesbian. She admits it. She said she just wanted to try to feel like a lesbian. Have a date and make love to women. I am only her experiment object" (Deojha, 2012: 69).

Lesbian relations also occur between Sangkhala Senja and Ninggar. Most of their sexual activities take place at home and in a romantic setting. The small stimuli that occurred between Sangkhala Senja and Ninggar created a sexual relationship that they both craved for. Hugging and kissing without wanting to let go of each other, as in the quote.

"And the eighteenth night of April ended with a warm and long kiss. Small gazes and touches that begin to deeper, the crazy thing I did; kissing and hugging your body later I found out, you have another lover. It's fine if you really just want to have fun with me." (Deojha, 2012:86).

The feelings of love and lust experienced by lesbians are not much different from hetero couples. The depiction of romantic love and lust as described by the author in the Sangkhala Senja's character can be seen in the following quote.

"As the game of truth or dare is over. You come closer and hug me. We were silent for a few moments to arrange each other's messy heart rhythms. And this is what I mean by a warm and long kiss. Your lips touch mine. Stick. Crushed. Soft, warm, and long this is how lesbians kiss. With heart". (Deojha, 2012: 90).

After Ninggar gone, Sangkhala Senja then gets comfort from Mayang's character. When Sangkhala Senja is hurt by Ninggar's abandonment, Mayang then appears as a little girl who becomes a new gift for Senja from God. Slowly, Sangkhala Senja teaches Mayang to play with her fantasy world, which is a little bit daring and naughty, as in the quote.

"I pulled her tiny body. For the first time I could feel the shape of her body which 
turned out to be beautiful. I put my lips on hers. I devoured with anger." (Deojha, 2012: 220).

The quote shows the sexual activity of Sangkhala Senja and Mayang. This can be seen from the choice of the word 'I put my lips on hers' which is usually associated with penetrative sexual activity, but they use to describe their primary sex. One of the most important things in sexual activity, called orgasm, can occur without involving differences in body anatomy.

\section{Main Characters in Responding to Heteronormativity Domination.}

Heteronormativity is a social construction that shows that sexual relations according to the norm are heterosexual.

Senja's presence at work place is a problem. Sangkhala Senja who is a lesbian was forced to be fired from her job, as in the quote.

"This is your salary for this month. Mm... Senja, why do you have to be a lesbian? You are pretty. Learn to like men." (Deojha, 2012:54).

From the quotation above, the discourse on heteronomativity clearly illustrates that the certainty of male and female identities is the main thing in social life. Since the heterosexual world only accepts two types of gender and sexual identities, namely male and female. It can also be seen in the following quote.

"After my face was shown on the $T$ without a word, many people started to keep their distance and be careful towards me." (Deojha, 2012: 204).

The quote shows that the discourse of heteronomativity of society considers a coherent identity to be the central identity, the truest identity. Means, someone will be considered righteous if the gender identity they display is in accordance with their body and sexual desires. In other words, if an individual has a female body, then their gender must show femininity and be sexually attracted to a male. The discourse of heteronomativity also occurs in friendship. It seen in the following quote.

"Pandhu told me a story which was struck by lightning and bitterness. There was a reality stolen from me, which I never had time to think about at least for the near future. You will get married. Not married to lesbian culture, but married in the truest sense. Marry a man." (Deojha, 2012: 241).

The quote shows that the relationship that exists between Pandhu and Sangkhala Senja is an unequal relationship. Pandhu, a friend of Sangkhala Senja, is an agent who brings "rules" to regulate the subjectivity of Sangkhala Senja's life which must be tied to various domestic discourses, especially her relationship with a man, as a woman. If a woman does not think about her future to get married, it becomes a social problem. Identity markers, such as the certainty of male and female identities, become the main thing to build a relationship, such as marriage. Since, for the heterosexual world, the institution of marriage only accepts two types of sexual and gender identities, called male and female.

\section{Conclusion}

In the novel Lesbian Laki-Laki (Male Lesbian) by Deojha, it can be seen that identity discourse is not only constructed by language but also through body markers. Both create identity boundaries that each individual must own. In heterosexual discourse, acceptable gender identity only consists of masculinity and femininity, then sexually, these differences are divided into two parts, namely male and female. This is why Sangkhala Senja has a female body but has soul masculinity which cannot be accepted in the discourse of individual identity. From this, it can be interpreted that this novel is still within the norms of heteronormativity. Through the queer discourse presented in Deojha's Lesbian Laki - Laki (Lesbian Male) novel, it can be seen that gender and sexual identity are not fixed but are a process of each identification.

\section{References}

Alimi, Moh. (2004). Yasir. Dekonstruksi Seksualitas Poskolinial, dari Wacana Bangsa hingga Wacana Agama. Yogyakarta: LKiS. Google Scholar

Beauvoir, S. D. (2003). The Second Sex atau Second Sex: Kehidupan Perempuan, terj. Toni B. Febriantono dan Nuraini Juliastuti. Jakarta: Pustaka Promethea.

Barry, Peter. (2010). Pengantar komprehensif teori sastra dan budaya: beginning 
theory. Yogyakarta: Jalasutra. Google Scholar

Blackwell, Christopher W., Ricks, Janice L., \& Dziegielewski, Sophia F. (2004). Discrimination of gays and lesbians: A social justice perspective. Journal of Health \& Social Policy, 19(4), 27-43. Google Scholar

Butler, Judith. (2002). Gender trouble. routledge. Google Scholar

Centhini, S., \& Lesbian, S. (n.d.). Fenomena Homoseksual Dalam Novel Indonesia Mutakhir. Google Scholar

Crowford. (2000). Pengertian Lesbianisme. Jakarta: Bumi Aksara.

Deojha. (2012). Lesbian Laki-laki. Yogyakarta: Lukita.

Fakih, M. (2013). Analisis Gender dan Transformasi Sosial (; Toto Rahardjo, Ed.). Yogyakarta: Pustaka Pelajar Offset. Google Scholar

Jagose, Annamarie, \& Genschel, Corinna. (1996). Queer theory. Melbourne University Press Melbourne.

Juditha, Christiany. (2014). Realitas lesbian, gay, biseksual, dan transgender (LGBT) dalam majalah. Jurnal Komunikasi, 6(3), 22-30. Google Scholar

Kasnadi, Kasnadi. (2017). Citra Lesbian
Dalam Novel Indonesia Awal Tahun 2000-An Karya Perempuan Pengarang. LITERA, 16(1). Google Scholar

Oetomo, Dede. (2001). Memberi suara pada yang bisu. Galang Press Yogyakarta. Google Scholar

Ritzer, George. (2012). Teori Sosiologi: Dari sosiologi klasik sampai perkembangan terakhir postmodern. Yogyakarta: Pustaka Pelajar, 11, 25. Google Scholar

Setyorini, Ari. (2011). Performativitas gender dan seksualitas dalam weblog lesbian di Indonesia. Jurnal Kawistara, 1(2). Google Scholar

Wahyudi, Nyoman Deni, \& Widhiasih, Luh Ketut Sri. (2015). Representasi Lesbian, Gay, dan Transgender dalam Antologi Cerpen Penjara: Sebuah Tinjauan Sosiopragmatik. Jurnal IImiah Pendidikan Citra Bakti, 2(1), 38-49. Google Scholar

Wiyatmi. (2007). Fenomena Homoseksual dalam Novel Indonesia Mutakhir. Jurnal DIKSI. 14(1). Retrieved from https://doi.org/10.21831/diksi.v14i1.655 1

Yanti, Devi Citra. (2016). Identitas Diri dan Orientasi Masa Depan Kaum Lesbian. Psikoborneo: Jurnal Ilmiah Psikologi, 4(4). Google Scholar

\section{Copyright holder :}

Agung Wijaksono, Nurhadi (2022)

First publication right :

Journal of Social Science

This article is licensed under: 